\title{
Evaluation of frothers based on properties of the solids/liquid/gas system
}

\author{
Jan Drzymala ${ }^{1, *}$ \\ ${ }^{1}$ Wroclaw University of Science and Technology, Faculty of Geoengineering, Mining and Geology, Wybrzeze \\ Wyspianskiego 27, 50-370 Wroclaw, Poland
}

\begin{abstract}
A methodology of selection of frothers for flotation process is presented in the paper. It is based on performing a series of fractionating flotation tests of a considered material at different doses of a selected frother and calculation of the mass balance of the process. Next, three steps are performed. The first one is determination of the frother dose and kinetic constant or specific rate, using the flotation limits plot relating maximum recovery and process rate, both at a selected maximum recovery of the considered material component. The second step is finding selectivity of separation by using the upgrading Fuerstenau plot, while the third element is frothers comparison plot in the form of selectivity versus process kinetics, at a selected maximum recovery, and also versus frother dose, for choosing the most suitable frother.
\end{abstract}

\section{Introduction}

Frothers play a vital role in flotation of ores, wastes and byproducts. Their role is to form froth and modify the properties of films between solid particles and bubbles as well as between bubbles [1, 2, 3, 4, 5, 6, 7]. Action of a frother depends on the type of material subjected to flotation. Literature data indicate that for highly hydrophobic solids frothers can sometimes be harmful while for medium hydrophobic is very effective and for weakly hydrophobic and hydrophilic is usually neutral [8]. In flotation other reagents are used, especially collectors. Their main role is to regulate hydrophobicity of the processed material, though some interactions between frother and collector take place $[9,10,11]$.

There are many classification of frothers which are used for evaluation flotation frothers. According to Bhattacharya and Dey [12] presently no accepted criteria for selection of frothers exist. Common sense suggests that the essential parameters which should be used for selection of frothers for industrial application are frother dose, flotation rate and process selectivity. These three parameters determine the cost of the beneficiation process. Therefore, the goal of this work is to propose a methodology which can be used for determination of the three essential process parameters, that is selectivity, power and kinesis provided by a frother in the solids/water/gas system during flotation process. Three plots will be used for this purpose, that is flotation limits graph, Fuerstenau upgrading curve and comparison relation.

\section{Mass balance of a hypothetical flotation process}

The base of all mineral processing considerations is the mass balance. The mass balance of a process can be calculated utilizing the grades of the feed $(\alpha)$, flotation concentrates $(\beta)$ and tailings $(v)$. The formulas for calculation of concentrate yield $\gamma$ is:

$$
\gamma=100 \% \frac{\alpha-v}{\beta-v},
$$

for recovery of a considered component in concentrates is

$$
\varepsilon=100 \% \frac{\alpha-v}{\beta-v} \cdot \frac{\beta}{\alpha},
$$

while for recovery of remaining components in the tailing

$$
\varepsilon_{r}=(100-\gamma) \frac{v}{(100-\alpha)}
$$

The mass balance of a hypothetical flotation process in which frother 1 was used is given in Table 1.

\footnotetext{
* Corresponding author: jan.drzymala@pwr.edu.pl
} 
Table 1. Mass balance of a hypothetical flotation process.

\begin{tabular}{|l|c|c|c|c|c|}
\hline \multicolumn{1}{|c|}{ Product } & $\begin{array}{c}\text { Flotation time, } \\
\text { min }\end{array}$ & $\begin{array}{c}\text { Yield } \\
\boldsymbol{\gamma}, \boldsymbol{\%}\end{array}$ & $\begin{array}{c}\text { Grade } \\
\boldsymbol{\beta}, \boldsymbol{\%}\end{array}$ & $\begin{array}{c}\text { Recovery } \\
\boldsymbol{\varepsilon} \boldsymbol{\%}\end{array}$ & $\begin{array}{c}\text { Remaining components recovery in } \\
\text { tailing, } \boldsymbol{\varepsilon}_{\mathbf{r}}, \boldsymbol{\%}\end{array}$ \\
\hline 1 & 1.1 & 3.46 & 30 & 52 & 98 \\
\hline $1+2$ & 2.3 & 5.76 & 25 & 72 & 95 \\
\hline $1+2+3$ & 4.1 & 15.45 & 11 & 85 & 62 \\
\hline $1+2+3+4$ & 14.0 & 39.20 & 5 & 98 & 0 \\
\hline Feed & & 100 & $2(\alpha)$ & 100 & \\
\hline
\end{tabular}

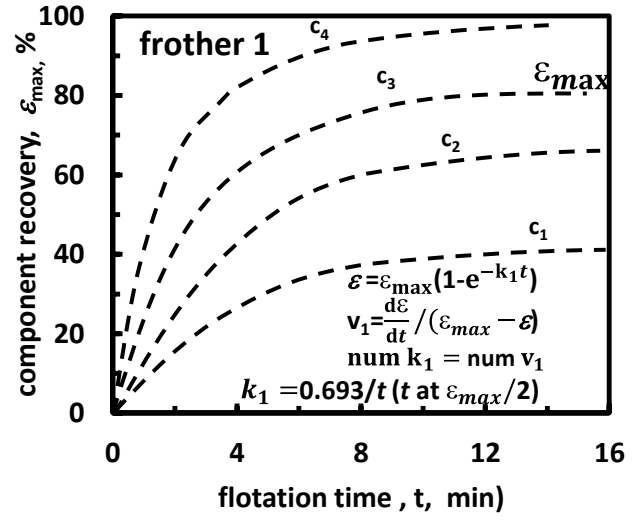

a)

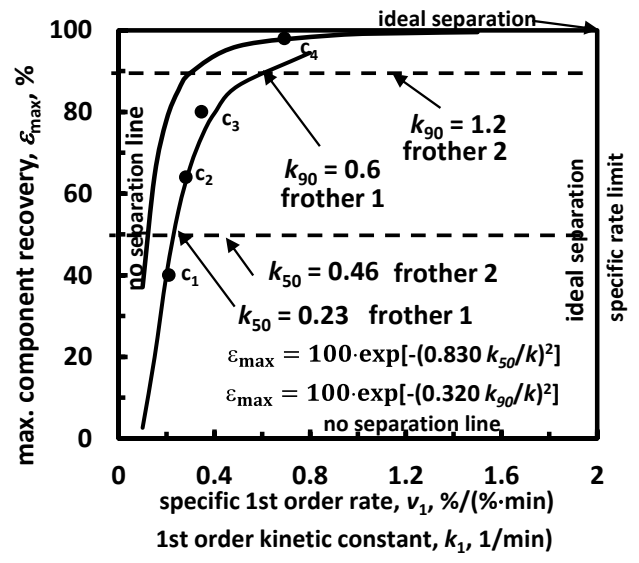

c)

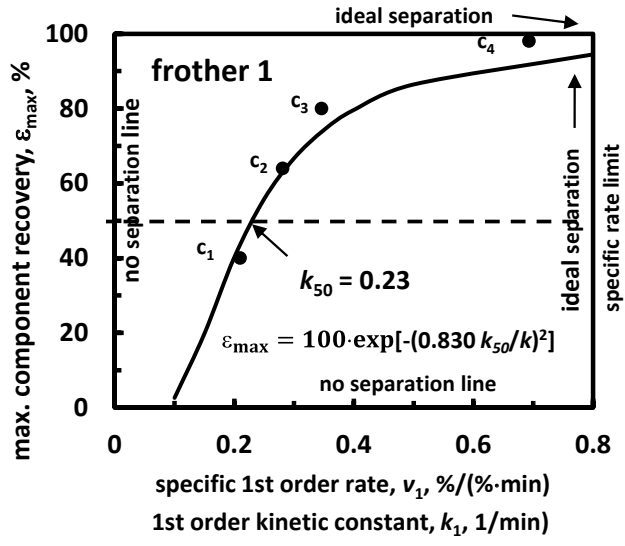

b)

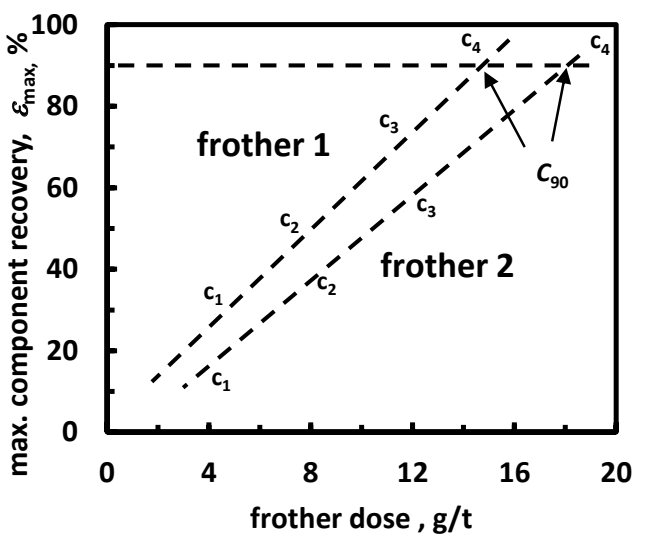

d)

Fig. 1. Evaluation of kinetics and dose of flotation frothers: a) kinetic curves, b) flotation limits curve, c) determination of kinesis that is $k$ at $\varepsilon_{\max }=90 \%$, d) determination of frother dose $C_{\varepsilon \max }$ at $\varepsilon_{\max }=90 \%$, that is $C_{90}$.

\section{Determination of kinesis of flotation and frother dose}

Frother must provide appropriate rate of the flotation process at a reasonable dose during the process. To determine both the frother dose and process rate, a series of flotation experiment at different doses of frother ought to be performed. Next, a separation balance should be performed as shown in Table 1. The mass balance is good base for plotting the recovery versus flotation time, which is presented in Fig. 1a. The experimental data are further processed by approximation of the experimental data with a mathematical equation having one fitting parameter as shown in Fig.1a. Very useful are the first order kinetic equations, both in differential and integral forms. The equations for the specific rate $(v)$ and rate constant $(k)$ are given in Fig. 1a. Index 1 for $k$ indicates that these parameters follow the $1^{\text {st }}$ order kinetics. Both $v_{1}$ and $k_{1}$ are numerically identical, though the specific rate is a more informative parameter because it has a physical meaning, that is indicates the speed of the process in the form of amount of solids of the considered component in concentrate per amount of solids in the flotation cell per unit time. Other kinetic equations can also be used [13, 14].

The kinetic plot (Fig. 1a) provides two parameters, that is maximum recovery $\left(\varepsilon_{\max }\right)$ and a constant $(v$ or $k$ ) along with information at what frother dose $(C)$ they were obtained. Next, the limits flotation curve [14] can be plotted as shown in Fig. 1b. The limits flotation curve indicates the maximum recovery $\varepsilon_{\max }$ that can be obtained 
at a specific flotation rate $(v$ or $k)$ and frother dose $C$. The advantage of the limits flotation curve is that one curve characterizes a flotation frother with just one curve. The course of the line can be approximated with an equation which is given in Fig. 1b. Since the goal is to compare different frothers, it is useful to draw the limits flotation curves for all of the considered frothers (Fig. 1c).

The dose of frothers $\left(C_{\varepsilon \max }\right)$ depends on the required maximum recovery, which is equivalent to a certain specific rate of the process. It is useful to set up the level of the maximum recovery. In Figure 1c two levels (50\% and $90 \%$ ) are indicated. The value of $k$ (or $v)$, at a certain level of $\varepsilon_{\max }$, is called the kinesis of the process $k_{\varepsilon_{\max }}$ [15]. If necessary, an addition plot can be created to determine precisely the dose for each frother at certain $\varepsilon_{\max }$ (Fig. 1d). Thus, the limits flotation curve provide the dose and kinetics (kinesis) of the process.

\section{Determination of selectivity of flotation and frother dose}

The selectivity of flotation and also the frother dose can be determined with the help of the upgrading plot, that is graphs relating quality and quantity of the separation process products. Very useful for this purpose is the Fuerstenau upgrading plot, relating recovery of a flotation feed component in flotation products $[16,17]$. There are four versions of the Fuerstenau upgrading curve [5]. The most useful modification is the one relating recovery of the considered component in concentrate $\varepsilon$ versus recovery of the remaining components in the tailing $\varepsilon_{r}$. The procedure of determination of the frother selectivity and dose, starts with the same mass balance of the process experimental data (Table 1). Next, the Fuerstenau plot is drawn (Fig. 2a). The experimental data has to be approximated with appropriate mathematical equations [18]. The most frequently used is the equation with one fitting parameter $a$. It has three forms:

$$
\begin{gathered}
a=\frac{\varepsilon \cdot \varepsilon_{r}}{\varepsilon+\varepsilon_{r}-100}, \\
a \cdot A=100 \%, \\
F^{2}-2 a F+100 a=0 .
\end{gathered}
$$

In this paper selectivity parameter $F$ is used, as shown in Fig. 2a.

The Fuerstenau curve provides two parameters [19]: power $(P)$, and selectivity of the frother $(F)$. The dose of frother depends on the criterion imposed on the flotation system. Since the frother dose $\left(C_{\varepsilon \max }\right)$ has been already established by means of the limits cure for $\varepsilon_{\max }=90 \%$, this parameter can be marked, as shown, in Fig. 2a. Another option is to read-off the frother dose from Fig. $2 \mathrm{a}$ at the cross point of the upgrading curve with the ascending diagonal. This parameter is called frother power $(P)$.

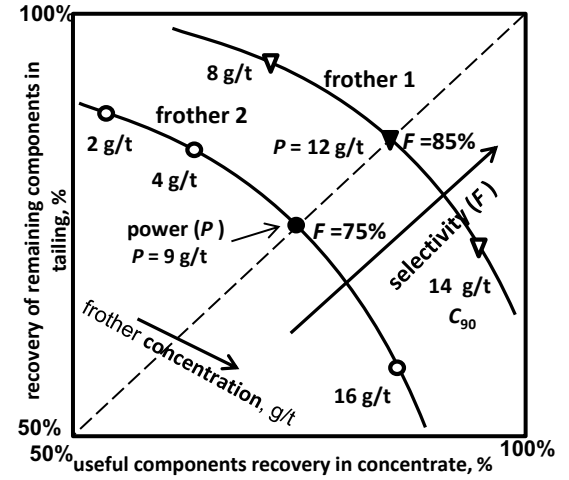

a)

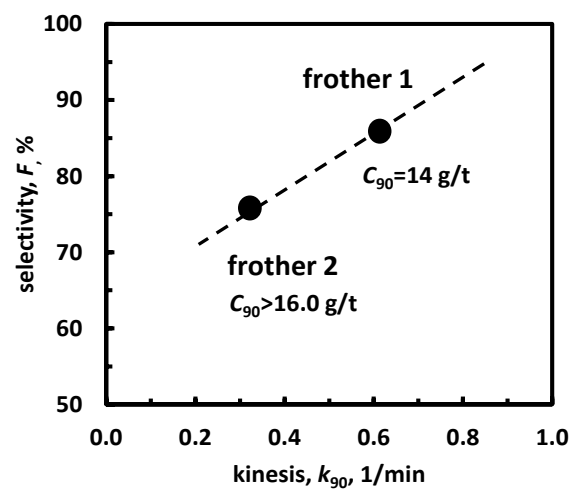

b)

Fig. 2a. Procedure of determination of selectivity $F(\%)$ and power $P(\mathrm{~g} / \mathrm{t})$ of flotation frothers using the Fuerstenau upgrading curve [19]. If used, the concentration of collector is constant.

Fig. 2b. A proposed graph for comparison of three parameters (kinesis $k_{90}$, selectivity $F$, and dose $C_{90}$ ) of each frother.

\section{Comparison of frothers}

Once the three most important flotation process results parameters, that is kinesis, dose (power) and selectivity of different frothers are determined, they can be compered for decision making purpose, leading to proper frother selection. Figure $2 \mathrm{~b}$ represents a proposition of such a graphical comparison method. According to Fig. 2b, hypothetical frother 1 is faster (greater $k_{90}$ ), has a smaller dose $\left(C_{90}\right)$ and better selectivity (greater $F$ ) than frother 2 . Thus this frother should be selected for the planned flotation process. In more complex cases, additional criteria may be needed for the final frother selection.

\section{Conclusions}

A selection of a frother for flotation process is possible by using three plots, that is limits plot used for determination of the frother dose and kinesis, the upgrading plot for selectivity determination and finally a comparison plot for a final decision.

The work was financed by the Polish Statutory Research Grant PWR/W6 for the year 2017/8. 


\section{References}

1. J. Czarnecki, K. Malysa, A. Pomianowski, J. Colloid Interface Sci. 86(2), 570-572, (1982)

2. D. Mobius, R. Miller, (Eds.), Studies in interface science, Novel methods to study interfacial layers, 11, 1-521, (Elsevier Science, 2001)

3. Y.S. Cho, J.S. Laskowski, Int. J. Miner. Process. 64(2-3), 69-80, (2002).

4. M.C. Fuerstenau, G.J. Jameson, R.H. Yoon, Froth flotation: A century of innovation. (SME Inc., Littleton, 2007)

5. J. Drzymala, Mineral Processing. Foundations of theory and practice of minerallurgy, 1st English Edition, (Oficyna Wydawnicza Politechniki Wroclawskiej, Wroclaw, 2007)

6. D. Kosior, J. Zawala, M. Krasowska, K. Malysa, Phys. Chem. Chem. Phys. 15, 2586-2595, (2013)

7. B.A. Wills, J.A. Finch, Wills' Mineral Processing Technology, 8th Ed., An introduction to the practical aspects of ore treatment and mineral recovery (Elsevier Ltd, Amsterdam, 2016)

8. J. Drzymala, P.B. Kowalczuk, A system of flotation frothers classifications, (in preparation, 2017)

9. J. Leja, J. H. Schulman, Trans. AIME 199, 221, (1954)

10. J. Lekki, J. Laskowski, Trans. IMM, Sec. C., 80, 174180, (1971)
11. D.J. Bradshaw, P.J. Harris, C.T. O'Connor, SAIMM, 98(4) 189-194, (1989)

12. S. Bhattacharya, S. Dey, Miner. Process. Extr. Metall. Rev., 29, 275-298, (2008)

13. X. Bu, G. Xie, Y. Peng, L. Ge, C. Ni, Physicochem. Probl. Miner. Process. 53(1), 342-365, (2017)

14. J. Drzymala, T. Ratajczak, P.B. Kowalczuk, Physicochem. Probl. Miner. Process. 53(2), 983-995, (2017)

15. J. Drzymała, M. Stodulski, Łupek miedzionośny III, Kowalczuk P.B., Drzymała J. (eds), (WGGG PWr, Wrocław, 167-171, 2017)

16. D.W. Fuerstenau, et al., Coal surface control for advanced fine coal flotation, (Final Report, University of California, Berkeley, Final Report DOE/PC/88878-T13, DE92 015625 for U.S. Dept. of Energy. Prepared by Univ. California, Columbia Univ., Univ. of Utah, and Praxis Engineers Inc., 1988-1992)

17. J. Drzymala, Physicochem. Probl. Miner. Process., 40, 19-29, (2006).

18. J. Drzymala, H.A.M. Ahmed, Int. J. Miner. Process. 76(1-2), 55-65, (2005)

19. P.B. Kowalczuk, J. Drzymala, Physicochem. Probl. Miner. Process. 53(1), 515-523, (2017) 